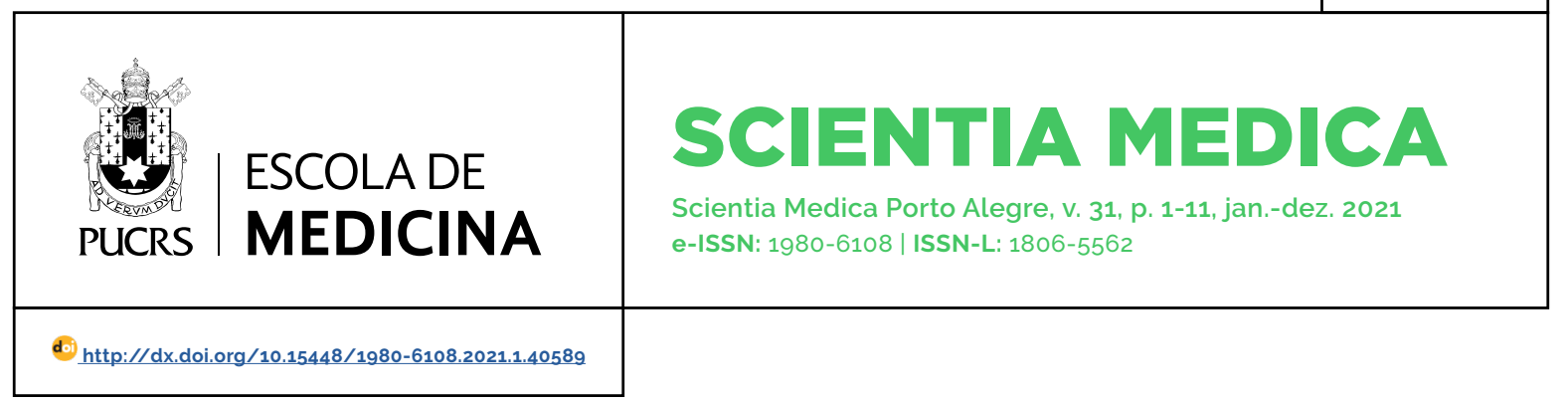

SEÇÃO: HISTORY OF MEDICINE

\title{
The 12 women who won the Nobel Prize in Medicine or Physiology
}

\author{
As 12 mulheres laureadas com o Prêmio Nobel de Medicina ou Fisiologia
}

\author{
Anna Maria Garcia \\ Cardoso ${ }^{1}$ \\ orcid.org/orcid.org/0000-0002- \\ 7174-4619 \\ annamariagarciacardoso@gmail.com
}

\section{Fernanda Santos Wengrover ${ }^{2}$}

orcid.org/0000-0001-8774-0199

fernandaswengrover@gmail.com

Marcelo Garcia Toneto ${ }^{1}$

orcid.org/0000-0003-4264-3808

mtoneto@terra.com.br

Received on: Apr. $2^{\text {nd }}, 2021$.

Approved on: Nov. $3^{\text {nd }}, 2021$.

Published on: Dec. $20^{\text {th }}, 2021$.

\section{(c) (i)}

Artigo está licenciado sob forma de uma licença Creative Commons Atribuicão 4.0 Internacional.

\begin{abstract}
Introduction: the Nobel Prize is one of the highest academic honors in the world. Since its first edition, in 1901, until 2021, there have been hundreds of winners. In the Medicine or Physiology category, chosen by the Karolinska Institute in Stockholm, Sweden, 112 awards have been given to 224 laureates, among them, only 12 (5.4\%) women.
\end{abstract}

Aims and source of data: with the aim of reviewing the biographies, characteristics, and peculiarities of each woman awarded the Nobel Prize for Medicine or Physiology. Data were analyzed from the following sources: the Award page, websites of the institutions to which some of them have been or are affiliated, books with biographies of Nobel laureates in Medicine or Physiology, and articles in the PubMed database.

Summary of findings: the average age when receiving the award was 63.4 years. The most recurrent country of origin was the United States of America, also responsible for the largest number of institutions to which the laureates were affiliated at the time of the award. The academic training of the laureates was quite diverse, ranging among medicine, chemistry, physics, biology, pharmacy, psychology and natural sciences. Five of the 12 laureates did not have children.

Comments: the origins and trajectories, although plural, have points in common, such as a fascination with science since childhood and the need to overcome additional barriers throughout their education, because of their sex.

Conclusion: investments on a global scale are necessary to increase equity between sexes.

Keywords: nobel prize, physiology, medicine, gender equality in health women, gender bias.

\section{Resumo}

Introdução: o prêmio Nobel é uma das maiores honrarias acadêmicas do mundo. Desde a sua primeira edição, em 1901, até 2021, já foram centenas de vencedores. Na categoria Medicina ou Fisiologia, escolhido pelo Instituto Karolinska em Estocolmo, na Suécia, foram entregues 111 prêmios para 224 laureados, dentre eles, apenas $12(5,4 \%)$ mulheres.

Objetivos e métodos: com o objetivo rever as biografias, características e peculiaridades, de cada mulher laureada com o prêmio Nobel de Medicina ou Fisiologia, foram analisados dados provenientes da página do prêmio; de sites das instituições às quais algumas delas foram ou são afiliadas; em livros com biografias dos laureados com o prêmio Nobel de Medicina ou Fisiologia; e artigos na base de dados PubMed.

Sintese dos dados: a média de idade ao receber o prêmio foi de 63,4 anos. O pais de origem mais recorrente foi os Estados Unidos da América; também é o local que abriga o maior número de instituições às quais as laureadas estavam filiadas no momento da premiação. A formação acadêmica das laureadas foi bastante diversa, variando entre: medicina, química, física, biologia, farmácia, psicologia e ciências naturais. Cinco das 12 laureadas não tiveram filhos. 
Conclusão: fazem-se necessários investimentos em escala global para aumentar a equidade entre os gêneros.

Palavras-chave: prêmio nobel, fisiologia, medicina, igualdade de gênero na saúde das mulheres, viés em relação ao gênero.

\section{Introduction}

The Nobel Prize is one of the highest honors in the scientific world in the categories of Physics, Chemistry, Medicine or Physiology, Literature, and Peace. The prizes were awarded for the first time in 1901 and there has been a ceremony almost annually since then, not taking place only in some periods during the 1st and 2nd World Wars. In 1968, the Bank of Sweden added the Nobel Prize for Economic Sciences (1, 2).

The name of the prize is attributed to Alfred Bernhard Nobel, a Swedish chemist and inventor, whose experiments with nitroglycerin led to the discovery of dynamite. This achievement boosted his economic life, leaving him with a great fortune. However, it cost the life of his younger brother in an experiment, in addition to expanding the war force of nations. When he died in 1895, Alfred, who by nature was a pacifist and had no direct family nucleus, left all his fortune in his will destined to honor "those who during the previous year had achieved the greatest benefit to humanity" $(1,2)$.

The first woman to receive the Nobel Prize was Marie Curie, in 1903. On this occasion, she shared the Physics Prize with her husband and with another researcher. In 1911, Curie won a second time, this time alone, in the Chemistry category. The first Nobel Prize in Medicine or Physiology was awarded to a woman only 44 years after Curie's achievement (2-5).

Since its first edition, in 1901, until 2021, there have been hundreds of winners. In the Medicine or Physiology category, chosen by the Karolinska Institute in Stockholm, Sweden, 112 awards have been given to 224 laureates, among them, only 12 (5.4\%) women (3).

The current study aims to review the biographies, characteristics, and peculiarities of each woman awarded the Nobel Prize for Medicine or Physiology, as well as to discuss the role of women as researchers in the scientific community.

\section{Methods}

The Nobel Prize for Medicine or Physiology laureates were reviewed. The material was researched in PubMed, directly on the Nobel Prize website, and in books with biographies of Nobel laureates in Medicine or Physiology. In addition, pages of the institutions to which they were or are affiliated were consulted.

\section{Results}

A general overview of the laureates, including the year of the laureate and the nature of the award-winning work, can be analyzed in Table 1. There is a large gap of three decades between the first and the second woman awarded the Prize, as well as an absence of female laureates between 2015 and the year of this publication, in 2021. The diversity among the themes of the awarded works is also noticeable $(1,2)$. 
TABLE 1 - The 12 women who won the Nobel Prize in Medicine or Physiology.

\begin{tabular}{|c|c|c|}
\hline LAUREATE & YEAR & PRIZE MOTIVATION \\
\hline 1. Gerty Theresa Cori & 1947 & $\begin{array}{l}\text { For their discovery of the course of the catalytic conversion of } \\
\text { glycogen }\end{array}$ \\
\hline 2. Rosalyn Yalow & 1977 & $\begin{array}{l}\text { For the development of radioimmunoassays of peptide } \\
\text { hormones }\end{array}$ \\
\hline 3. Barbara McClintock & 1983 & For her discovery of mobile genetic elements \\
\hline 4. Rita Levi-Montalcini & 1986 & For their discoveries of growth factors \\
\hline 5. Gertrude B. Elion & 1988 & For their discoveries of important principles for drug treatment" \\
\hline $\begin{array}{l}\text { 6. Christiane } \\
\text { Nüsslein-Volhard }\end{array}$ & 1995 & $\begin{array}{l}\text { For their discoveries concerning the genetic control of early } \\
\text { embryonic development }\end{array}$ \\
\hline 7. Linda B. Buck & 2004 & $\begin{array}{l}\text { For their discoveries of odorant receptors and the organization of } \\
\text { the olfactory system }\end{array}$ \\
\hline 8. Françoise Barré-Sinoussi & 2008 & For their discovery of human immunodeficiency virus \\
\hline 9. Elizabeth H. Blackburn & 2009 & $\begin{array}{l}\text { For the discovery of how chromosomes are protected by } \\
\text { telomeres and the enzyme telomerase }\end{array}$ \\
\hline 10. Carol W. Greider & 2009 & $\begin{array}{l}\text { For the discovery of how chromosomes are protected by } \\
\text { telomeres and the enzyme telomerase }\end{array}$ \\
\hline 11. May-Britt Moser & 2014 & $\begin{array}{l}\text { For their discoveries of cells that constitute a positioning system } \\
\text { in the brain }\end{array}$ \\
\hline 12. Tu Youyou & 2015 & For her discoveries concerning a novel therapy against Malaria \\
\hline
\end{tabular}

Table 2 presents a summary of the laureate data. Although the Nobel Prize for Medicine or Physiology has been awarded since 1901, the first woman to win the award was only 46 years later. Since then, another 11 women have been honored with the award. The average age when receiving the award was 63.4 years. The most recurrent country of origin was the United States of America, also the place that houses the largest number of institutions to which the laureates were affiliated at the time of the award. The academic training of the laureates was quite diverse, ranging from: medicine, chemistry, physics, biology, pharmacy, psychology, and natural sciences, which speaks in favor of stimulating interdisciplinary training and science in general. Therefore, the discoveries are equally diverse, as well as their applicability (1, 2, 6-24). 
TABLE 2 - Characteristics of the 12 women who won the Nobel Prize in Medicine or Physiology.

\begin{tabular}{|c|c|c|c|c|}
\hline Name & Age & Degree & Nationality & Prize Share \\
\hline $\begin{array}{l}\text { Gerty Cori } \\
1886-1957\end{array}$ & 61 & Medicine & $\begin{array}{l}\text { Czech } \\
\text { Republic }\end{array}$ & $\begin{array}{l}\text { Carl Ferdinand Cori* (Czech } \\
\text { Republic) \& Bernard Houssay } \\
\text { (Argentina) }\end{array}$ \\
\hline $\begin{array}{l}\text { Rosalyn Yalow } \\
1921-2011\end{array}$ & 56 & Physics & USA & $\begin{array}{l}\text { Roger Guillemin (France) \& Andrew } \\
\text { V. Schally (Lithuania) }\end{array}$ \\
\hline $\begin{array}{l}\text { Barbara McClintock } \\
\text { 1902-1992 }\end{array}$ & 81 & Biology & USA & -- \\
\hline $\begin{array}{l}\text { Rita Levi- Montalcini } \\
\text { 1909-2012 }\end{array}$ & 77 & Medicine & Italy & Stanley Cohen (USA) \\
\hline $\begin{array}{l}\text { Gertrude B. Elion } \\
\text { 1918-1999 }\end{array}$ & 70 & Chemistry & USA & $\begin{array}{l}\text { James W. Black (Scotland) \& } \\
\text { George H. Hitchings (USA) }\end{array}$ \\
\hline $\begin{array}{l}\text { Christiane Nüsslein- Volhard } \\
1942 \text { - }\end{array}$ & 53 & Biochemistry & Germany & $\begin{array}{l}\text { Edward B. Lewis (USA) \& Eric F. } \\
\text { Wieschaus (USA) }\end{array}$ \\
\hline $\begin{array}{l}\text { Linda B. Buck } \\
\text { 1947- }\end{array}$ & 57 & Biology & USA & Richard Axel (USA) \\
\hline $\begin{array}{l}\text { Françoise Barré-Sinoussi } \\
\text { 1947- }\end{array}$ & 61 & $\begin{array}{l}\text { Natural } \\
\text { Sciences }\end{array}$ & France & $\begin{array}{l}\text { Harald zur Hausen (Germany) \& } \\
\text { Luc Montagnier (France) }\end{array}$ \\
\hline $\begin{array}{l}\text { Elizabeth Blackburn } \\
\text { 1948- }\end{array}$ & 61 & Biochemistry & Australia & $\begin{array}{l}\text { Carol W. Greider (USA); } \\
\text { Jack W. Szostak (England) }\end{array}$ \\
\hline $\begin{array}{l}\text { Carol W. Greider } \\
\text { 1961- }\end{array}$ & 48 & Biology & USA & $\begin{array}{l}\text { Elizabeth H. Blackburn (Australia); } \\
\text { Jack W. Szostak (England) }\end{array}$ \\
\hline $\begin{array}{l}\text { May-Britt Moser } \\
\text { 1963- }\end{array}$ & 51 & Psychology & Norway & 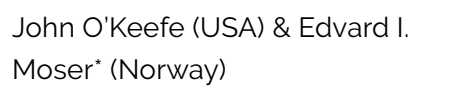 \\
\hline $\begin{array}{l}\text { Tu Youyou } \\
\text { 1930- }\end{array}$ & 85 & Pharmacy & China & $\begin{array}{l}\text { William C. Campbell (Ireland) \& } \\
\text { Satoshi Ōmura (Japan) }\end{array}$ \\
\hline
\end{tabular}

"Spouse.

Of the 112 editions, only 39 Awards were given to a single researcher - 38 men and only one woman, Barbara McClintock, in 1983. The other women shared the award, two of them with their spouses and a third researcher (1, 2, 6-24).

\section{The pioneers: Gerty \& Rosalyn}

The first woman to be awarded the Nobel Prize in Physiology and Medicine, Gerty Theresa Cori, was born in 1896 in Prague, then the Austro-Hungarian Empire. In 1914, she enrolled in medicine at the German University of Prague, where she met Carl Ferdinand Cori, who she married in 1920 , 
the year of her graduation. She emigrated to the United States two years later, with her husband. The reasons for this change arise from the fact that Europe was recovering after the First World War and the fact that Gerty was a woman with Jewish heritage made it even more difficult to build an academic career. In Buffalo, New York, at the State Institute for the Study of Malignant Diseases (now Roswell Park Memorial Institute) she was employed on less favorable terms than her husband. The couple even heard that it was "unAmerican" for a couple to work together. Despite this, they started their research on metabolic mechanisms. In 1931, they were offered positions at the University of Washington in St. Louis, where they moved. Their only son was born there in 1936. Carl soon assumed the position of president at the School of Medicine, but Gerty would only enter, as a researcher, in 1946, receiving ten percent of her partner's salary to perform the same function. She became a teacher in 1947. the same year she was awarded the Nobel Prize, at the age of 51, with her husband and another researcher. The couple's mutual interest in metabolic and hormonal pathways led them to study and describe mechanisms of action of glands, such as the pituitary, and of enzymes, such as glucose-1-phosphate (Cori ester), responsible for glucose metabolism pathways $(2,4,6,7,8)$.

Thirty years went by before another woman was awarded the Nobel Prize in Physiology and Medicine. In 1977, Rosalyn Yalow received the award along with two other researchers for their discoveries about peptide hormones that culminated in the development of the radioimmunoassay technique, capable of dosing minute amounts of substances in the blood and in other body fluids. With a Jewish heritage, Rosalyn, born in 1921 in New York City, was brilliant since childhood. She attended Hunter College (now City University of New York), and developed an interest in physics, which upset her family, who thought it was more appropriate for her to work as a primary school teacher. As soon as she graduated, in 1941, Yalow was invited to teach physics at the University of Illinois. She was the only woman among the institution's 400 employees. Two years after completing her doctorate in 1947. Rosalyn earned a position as a researcher at the Bronx Veterans Administration Hospital, where she began to study the medicinal use of radioisotopes. For more than two decades, she and Doctor Solomon Berson worked to develop the technique of using radioisotopes to trace the metabolism of substances, such as insulin, by analyzing the radioactive decay of the injected matter in patients. In the 1970s, they were able to describe, through this technique, the behavior of other hormones. During that time, she and her husband had two children. Her colleague Berson passed away in 1972, so was unable to share with her the Nobel Prize that came five years later $(2,4,9,10)$.

\section{The laureles of the 1980s: Barbara, Rita and Gertrude}

The third woman to earn the Nobel Prize in Physiology and Medicine, in 1983. Barbara McClintock, is responsible for discoveries in the field of genetics. She was the only woman to receive the award alone. Like her predecessors, she had to overcome adversities related to her sex to develop a career as a scientist. Born in 1902 in Connecticut, Barbara thwarted her parents' desire for her to be married off and began her studies at Cornell's College of Agriculture in 1919. She soon discovered her passion for genetics, a field which was still incipient, which she studied throughout her life. McClintock, through the study of corn, was able to prove, between the 1940 s and 1950s, that genetic elements can be activated or deactivated through the transposition of certain genes within a chromosome - a fact that explains the functioning of the laws observed by Mendel in the previous century. Her work enabled better understanding of the genetic variability of beings, as well as the mechanisms that influence it. Barbara chose never to get married or have children $(2,4,11)$.

Rita Levi-Montalcini was the fourth woman to receive the Nobel Prize in Physiology and Medi- 
cine, in 1986, along with her colleague Stanley Cohen. They discovered and described Nerve Growth Factor, which subsequently allowed for better understanding of diseases such as Alzheimer's and cancer. Rita was born into a wealthy Jewish family in the city of Turin, Italy, in 1909. At the age of twenty, she asked her father for permission to break with the expectation of assuming the role of wife and mother in order to pursue a professional career. She entered the School of Medicine of her hometown, despite having considered a career as a writer. She graduated in 1936 and started specializing in neurology and psychiatry in Brussels. In the same year, the Racial Laws (Manifesto per la Difesa della Razza) were decreed by Mussolini, making it impossible for her to complete the course and forcing her to return home. Isolated from the "Aryan world", she set up a small laboratory in her room, inspired by Viktor Hamburger's 1934 article on the effects of limb removal in chicken embryos. Less than a year later, as a result of the war, she was forced to relocate her mini laboratory to a hut in the countryside. In 1943 she was forced to flee to Florence, where she worked as a doctor in the refugee camp in the Anglo-American barracks until the end of the war. She was subsequently able to continue her research, being invited to work in the USA, with the author of the article that had inspired her years before. In 1952, she succeeded in isolating a substance removed from cancer cells in rats that, when administered to chicken embryos, caused a remarkable growth in the nervous system - a molecule that would later be called Nerve Growth Factor. Levi-Montalcini never married or had children. She passed away in 2012, at the age of 103 - thus being the most longevous Nobel laureate of all categories $(2,4,12)$.

Two years later, in 1988, American chemist Gertrude B. Elion shared the Prize with two other scientists for the discovery of the principles of drug treatment. Daughter of Lithuanian and Russian immigrants, Gertrude was born in 1918 in New York City. She studied biochemistry at Hunter College, the same one at which Rosalyn Yalow (1977 laureate) had completed her physics training.
After graduating in 1937, at just 19 years of age, she found it difficult to exercise her profession, as the laboratories did not hire the few women trained in the area. Unemployed, she randomly met a chemist and started working as an assistant in his laboratory, initially on an unpaid basis. In 1929, she entered a master's degree in chemistry at New York University, as the only woman on the course. During this period, she took up the position of a teacher at Secondary Schools in New York City, having only the night shift and weekends to dedicate to her research. During the Second World War, she was hired by laboratories, but not as a researcher. She was finally accepted into a research laboratory, as an assistant to George $\mathrm{H}$. Hitchings, with whom she shared the Prize years later. During this period, she started her doctorate on a night shift at the Brooklyn Polytechnic Institute, but eventually dropped out. The subsequent years were filled with small biochemical-metabolic discoveries, which came to fruition in the late 1950s, with the creation of new drugs, capable of altering the course of diseases such as leukemia. She also created the first successful antiviral drug, Acyclovir, as well as many others. Her name is associated with the patent of 45 drugs. In 1983 she took the Presidency of the American Association for Cancer Research. Gertrude also served as a counselor at the National Cancer Institute of the World Health Organization. She never married or had children $(2,4,13,14)$.

\section{Christiane: the only laureate of the $1990 \mathrm{~s}$}

Christiane Nüsslein-Volhard was the sixth woman to receive the Award, in 1995, at the age of 53, for her discoveries about the genes involved in early embryonic development. Born in 1942 during World War II into a large and close-knit German family, Christiane had a happy childhood. She attended a month of nursing school in a hospital, considering the possibility of becoming a doctor. She soon gave up and studied biology at Goethe University in Frankfurt. In 1964, she entered the then unprecedented biochemistry course in Tübingen, where she obtained her diploma in 1969, with mediocre grades. At that time, little 
was known about the mechanisms involved in the complex process of embryogenesis, which became her emphasis. Nüsslein-Volhard was able to describe a series of genetic-embryonic signaling pathways, including the Hedgehog pathway - responsible for determining the correct development of the embryo. She also discovered that signaling proteins in this pathway are also active during adulthood, their failure being associated with the appearance of some types of cancer. Faced with the challenges she had to overcome in order to achieve her professional goals simply because she was a woman, in 2004 she founded the Christiane Nüsslein-Volhard Stiftung Foundation, whose main objective is to provide support for women scientists to continue their research during motherhood. Christiane Nüsslein-Volhard had no children $(2,15,16,17)$.

\section{The 2000s: Linda, Françoise, Elizabeth, Carol \& May-Britt}

The seventh woman to receive the Nobel Prize in Physiology or Medicine was in 2004. Linda Buck is responsible for the study and description of the processing mechanism of olfactory stimuli. Linda was born in Seattle, USA, in 1947. She initially started a psychology degree at the University of Washington, but soon switched to microbiology, obtaining her degree in 1975, where she had her first contact with research. She continued her studies in Dallas, at the University of Texas, where she earned her PhD in immunology, in 1980. Fascinated with membrane proteins, still little explained, she advanced her studies on the Major Histocompatibility Complex and its action on antigen-antibody interactions in the context of immunology. To deepen her research, she was transferred to Richard Axel's laboratory, with whom she would associate. Linda then learned about neuroscience, which captivated her, prompting her to continue researching in this area. Reading a 1985 article by scientist Sol Snyder about potential odor detection mechanisms, she asked herself: how can such similar molecules determine such different smells and how do we detect and interpret them? Extremely motivated to solve these mysteries, she started her research on odor receptors in 1988. In 1991, Linda and her colleague Richard were able to demonstrate and publish about the genes responsible for olfactory receptors in nasal neurons. That same year, Linda left for Boston, taking up the position of assistant professor in the neurobiology department at Harvard Medical School. In 2002 she returned to her hometown, now as a member of the Division of Basic Sciences at the Fred Hutchinson Cancer Research Center and as a professor of physiology and biophysics at the University of Washington, where she carried on her research on olfactory mechanisms, which continues until today (18).

Four years later, in 2008, Françoise Barré-Sinoussi became the eighth woman to receive the Nobel Prize in Physiology or Medicine. She was co-responsible for the discovery of the HIV virus. Born in Paris in 1947. Françoise has been interested in science since childhood. During her graduation in natural sciences, she got in touch with several laboratories, offering to work as a volunteer in order to gain experience. She was accepted into a group affiliated with the Pasteur Institute, which studied the relationship between cancers in rats and retroviruses. She received her doctorate in 1974 from the Faculty of Sciences at the University of Paris and soon started a postdoctoral study in the USA, with scientists from the National Cancer Institute (NCI). She spent only one year in America, where she met her future husband, before returning to work at the Pasteur Institute, still studying the relationship between retroviruses and cancer. As soon as the suspicion arose that a new pandemic was emerging. she contacted virologist Luc Montagnier, and together they worked to determine its cause. In 1983, they were able to isolate the virus that caused the Acquired Human Immunodeficiency Syndrome. Françoise devoted the rest of her career to unraveling the mysteries of the virus she had discovered, investing her time and energy in researching it, and always collaborating with countries that had less resources. She retired in 2017, having received more than 10 laureates, in addition to the title of Doctor Honoris Causa from 
several universities (19, 20).

The following year, in 2009, two women were together awarded the Nobel Prize in Physiology or Medicine, for the first time in history. Carol W. Greider and her supervisor Elizabeth H. Blackburn shared the prize with colleague Jack W. Szostak for their discovery of how chromosomes are protected by telomeres and the telomerase enzyme (1, 21, 22).

Elizabeth $\mathrm{H}$. Blackburn was born in Australia in 1948, daughter of a family of doctors. Passionate about nature and animals, the study of biology came naturally to her. Reading the biography of scientist Marie Curie also influenced her decision. She graduated from the University of Melbourne in biochemistry and was immediately offered a position in the research laboratory, where she studied the metabolism of amino acids. Her professor arranged a place for her at Cambridge as a PhD student. There, immersed in the world of molecular biology, she researched the DNA sequencing of a bacteriophage virus, which later culminated in the analysis of DNA sequence patterns. As a very able student, she found herself surrounded by possibilities. In 1975, although initially determined to do her postdoctoral studies at the University of California San Francis$\mathrm{co}$, in the USA, she changed her course to Yale University, because of her husband. In 1977, she concluded the thesis on the DNA sequencing of small protozoa, and moved to take a position at University of California San Francisco, along with her husband. Elizabeth continued her studies, analyzing the terminal portions of chromosomes, the telomeres. Finally, she was able to prove the importance of these structures for longevity and to demonstrate how our habits are responsible for shaping their function (21).

Carol W. Greider was the youngest woman to receive the Award, at the age of 48 . Daughter of academic parents, Carol was born in San Diego, California, USA, in 1961. Carol had difficulties at school, as she is dyslexic. In 1971, her father was invited to work at the Max Planck Institute in nuclear physics in Germany. There, she attended the local school, learning the language by immersion.
The family returned in time for Carol to enter high school. Later, when visiting the University of California in Santa Barbara, she was captivated by the marine ecology course. There, she was encouraged to work in the laboratory from the first year of college. She spent the second year of graduation at the University of Göttingen, in Germany, taking the opportunity to study abroad offered by her university. Her advisors contacted researchers at the Max Planck Institute, the same place as her father had worked years before, which allowed her to continue working in their laboratories. There she studied chromosomes for the first time. Back in Santa Barbara, she completed her graduation with mediocre grades, which caused difficulties when applying to other courses. It was in an interview at the University of California, Berkeley, that she met Elizabeth Blackburn, who was to become her master and, later, colleague. Together, in 1984, they started working to answer questions still pending on telomeres. In December 1985, the research was published. Afterwards, she spent a period at the Cold Spring Harbor Laboratory, until joining the department of molecular biology and genetics at Johns Hopkins University School of Medicine, where she continues to study telomerase until the present day (22).

May-Britt Moser was the eleventh woman to receive the Nobel Prize in Physiology or Medicine, along with her husband and another scientist. In 2014, their discoveries about the cells that make up the brain's positioning system were awarded. Born in 1963, in Norway, May-Britt spent her childhood like some of the other laureates, observing and interacting with animals and plants, not always with the best grades in the class. She married a high school classmate, Edvard Moser, in 1985. Together, they decided to graduate in psychology. In the second semester, they began to study the behavior of rats in the laboratory. Delighted by the possibility of unraveling the relationship between the brain and behavior, they engaged in master's and, later, doctorate projects on the subject. Their first daughter was born in 1991, shortly after the beginning of May-Britt's PhD. The focus of the 
couple's research was directed to the region of the brain called the hippocampus, responsible for the processing of memory. The couple's second daughter was born in 1995, just before the defense of her PhD thesis. Breastfeeding in public, taking the children to scientific meetings and to the laboratory, she continued her studies, which reaffirmed and expanded her previous findings. The couple moved to Edinburgh, Scotland, and later to London, England. There, they worked together in the laboratory of scientist John O'Keefe, with whom they would come to share the Nobel Prize. In 1996, the couple returned to Norway to take up professor-researcher positions at the Norwegian University of Science and Technology in Trondheim, positions they hold until today (23).

\section{Tu Youyou: when traditional chinese medicine and western medicine meet}

The twelfth woman, and last, to date, to receive the Nobel Prize in Medicine or Physiology was born in China in 1930. Developer of two drugs used in the treatment of malaria, Tu Youyou was also the first Chinese citizen to be awarded the Nobel Prize in any category. All her studies and work took place within her country. Due to her illness with tuberculosis at the age of 16 , she chose to work in the search for cures for diseases. As a student in the Pharmacy department at the Medical School of Peking University, she received instruction on plants used in Traditional Chinese Medicine, learning how to classify, identify, and use them. Along with her professor, Lou Zhicen, she took a step forward, extracting the active molecules from plants and determining the structure of the molecules. As soon as she graduated in 1955, Tu Youyou was employed at the Institute of Chinese Materia Medica of the new Academy of Traditional Chinese Medicine (now China Academy of Chinese Medical Sciences), subordinate to the Chinese Ministry of Health. There, she continued her research, exploring the molecular bases and mechanisms of action of treatments with medicinal herbs, in resonance with a government policy of integrating Western medical knowledge with traditional Chinese me- dicine, which proved extremely beneficial for patients. In the late 1960s, a potentially fatal disease went out of control: malaria became resistant to drugs. In this context, thousands of soldiers from the Vietnam War were dying from this disease. In 1964, Chinese military institutes founded a secret project to discover a new antimalarial drug. In 1969, during the Great Chinese Cultural Revolution, Tu Youyou was appointed head of the team of researchers responsible for developing the drug. This directly impacted her personal life: Youyou left her four-year-old daughter with her parents and her one-year-old daughter with the daycare teacher's family. Three years later, when she visited them, they did not recognize her. Tu Youyou's long journey through traditional literature and laboratory experiments has brought results. The discovery of the drug artemisinin meant the survival of hundreds of thousands of people. Tu Youyou, today, at the age of 90 , is still a professor and researcher at the China Academy of Traditional Chinese Medicine (24).

\section{Final considerations}

Between 1901 and 2021, 975 laurels were awarded in all Nobel Prize categories. Of these almost one thousand recipients, only 58 (5.9\%) are women. In the same period, of the 224 laureates awarded exclusively for the Nobel Prize in Medicine or Physiology, 12 (5.4\%) were for women (1, 3). Inequality between sexes in the academic world, evidenced with less representativeness in publications, number of articles published, number of citations, and lower salary, is a global problem that has been perpetuating over the decades, being even more prominent in researchers from high impact and leadership positions $(25,26,27)$.

The pioneers, Gerty Cori and Rosalyn Yallow, had one and two children, respectively. The seven women who were laureates in the sequence (Barbara McClintock, Rita Levi-Montalcini, Gertrude B. Elion, Christiane Nüsslein-Volhard, Linda B. Buck, Françoise Barré-Sinoussi, and Elizabeth $\mathrm{H}$. Blackburn) had no children. Finally, the last three, Carol W. Greider, May-Britt Moser, and Tu Youyou are mothers of two children each. The issue of 
the impact of motherhood is also addressed in studies, reinforcing that the double shift (maternity and academia) presents a series of difficulties for scientists who choose to become mothers (28). Examples such as the Christiane Nüsslein-Volhard Stiftung Foundation, by Christiane Nüsslein-Volhard are commendable, but public and private policies are necessary to support the careers of research mothers.

Each laureate, whose stories present their peculiarities, different academic backgrounds, upbringing, and ways of dealing with adversity, serves as a source of inspiration for the different potentials in the female world. In view of the disparity that surrounds the female world in science, investments on a global scale are necessary to increase gender equity.

\section{Notes}

The version of the article was reviewed by Robin Hambly.

\section{Funding}

This study did not receive financial support from external sources

\section{Conflicts of interest disclosure}

The authors declare no competing interests relevant to the content of this study.

\section{Authors' contributions}

All the authors declare to have made substantial contributions to the conception, or design, or acquisition, or analysis, or interpretation of data; and drafting the work or revising it critically for important intellectual content; and to approve the version to be published.

\section{Availability of data and responsibility for the results}

All the authors declare to have had full access to the available data and they assume full responsibility for the integrity of these results.

\section{References}

1. The Nobel Prizes. Nobel Prize facts [Internet]. NobelPrize.org. Nobel Prize Outreach AB; 2021 lcited 2021 Oct 13]. Available from: https://www.nobelprize.org/ prizes/facts/nobel-prize-facts

2. Noro JJ. Nobel - O Prêmio e o Homem: Prêmios Nobel de Fisiologia e Medicina. São Paulo: JSN Editora; 1999.

3. The Nobel Prizes. All Nobel Prizes in Physiology or Medicine [Internet]. NobelPrize.org. Nobel Prize Outreach AB; 2021 [cited 2021 Oct 13]. Available from: https://www.nobelprize.org/prizes/lists/all-nobel-laureates-in-physiology-or-medicine

4. McGrayne SB. Mulheres que ganharam o Prêmio Nobel em Ciências: suas vidas, lutas e notáveis descobertas. São Paulo: Editora Marco Zero; 1994.

5. Dall'ava-Santucci J. Mulheres e médicas: As pioneiras da medicina. Rio de Janeiro: Ediouro; 2005.

6. The Nobel Prizes. Gerty Cori - Biographical [Internet]. NobelPrize.org. Nobel Media AB; 2021 [cited 2021 Oct 13]. Available from: https://Www nobelprize.org/prizes/ medicine/1947/cori-gt/lecture

7. American Chemical Society National Historic Chemical Landmarks. Carl and Gerty Cori and Carbohydrate Metabolism [Internet]. American Chemical Society: Washington, USA; 2004 Sep 21 [cited 2020 May 21]. Available from: https://www.acs.org/content/acs/en/ education/whatischemistry/landmarks/carbohydratemetabolism.html

8. Litoff JB, McDonald J. European Immigrant Women in the United States: A Biographical Dictionary. New York \& London: Garland Publishing; 1994.

9. The Nobel Prizes. Rosalyn Yalow - Biographical [Internet]. NobelPrize.org. Nobel Media AB; 2021 [cited 2021 Oct 13]. Available from: https://www.nobelprize. org/prizes/medicine/1977/yalow/biographical

10. Glick S. Rosalyn Sussman Yalow (1921-2011). Nature. 2011:474(7353):580. https://doi.org/10.1038/474580a

11. The Nobel Prizes. Barbara Mcclintock - Biographical [Internet]. NobelPrize.org. Nobel Media AB; 2021 [cited 2021 Oct 13]. Available from: https://www.nobelprize. org/prizes/medicine/1983/mcclintock/biographical

12. The Nobel Prizes. Rita Levi-Montalcini - Biographical [Internet]. NobelPrize.org. Nobel Media AB; 2021 [cited 2021 Oct 13]. Available from: https://Www nobelprize. org/prizes/medicine/1983/mcclintock/biographical

13. The Nobel Prizes. Gertrude B. Elion - Biographical [Internet]. NobelPrize.org. Nobel Media AB; 2021 [cited 2021 Oct 13]. Available from: https://www.nobelprize. org/prizes/medicine/1988/elion/biographical

14. Academy of Achievement. Gertrude B. Elion Biography - Academy of Achievement. [Internet]. Last modified February, 92021 [cited 2021 May 23]. Available from: https://achievement.org/achiever/gertrude-elion 
15. The Nobel Prizes. Christiane Nüsslein-Volhard Biographical [Internet]. NobelPrize.org. Nobel Media AB; 2021 [cited 2021 Oct 13]. Available from: https:// Www.nobelprize.org/prizes/medicine/1995/nusslein-volhard/biographical

16. Christiane Nüsslein-Volhard: cientista que ajudou a decifrar o embrião. Bayer.com [Internet]; 2019 [cited 2020 May 23]. Available from: https://www.canwelivebetter.bayer.com.br/saude/christiane-nusslein-volhard-cientista-que-ajudou-decifrar-o-embriao

17. Nüsslein-Volhard C. Foundation for the Support of Female Scientists with Children [Internet]; 2004. Tübingen: Christiane Nüsslein-Volhard-Stiftung [cited 2020 May 23]. Available from: https://cnv-stiftung.de/ en/background

18. The Nobel Prizes. Linda B. Buck - Biographical [Internet]. NobelPrize.org. Nobel Media AB; 2021 [cited 2021 Oct 13]. Available from: https://www nobelprize. org/prizes/medicine/2004/buck/biographical

19. The Nobel Prizes. Françoise Barré-Sinoussi - Biographical [Internet]. NobelPrize.org. Nobel Media AB; 2021 [cited 2021 Oct 13]. Available from: https://www. nobelprize.org/prizes/medicine/2008/barre-sinoussi/ biographical

20. The Institut Pasteur. Françoise Barré-Sinoussi, Born In 1947 [Internet]. Paris: Institut Pasteur; [cited 2020 May 24]. Available from: https://www.pasteur.fr/en/institut-pasteur/history/francoise-barre-sinoussi-born-1947

21. The Nobel Prizes. Elizabeth H. Blackburn - Biographical [Internet]. NobelPrize.org. Nobel Media AB; 2021 [cited 2021 Oct 13]. Available from: https://WwW. nobelprize.org/prizes/medicine/200g/blackburn/ biographical

22. The Nobel Prizes. Carol W. Greider - Biographical [Internet]. NobelPrize.org. Nobel Media AB; 2021 [cited 2021 Oct 13]. Disponivel em: https://www.nobelprize. org/prizes/medicine/2009/greider/biographical

23. The Nobel Prizes. May-Britt Moser - Biographical [lnternet]. NobelPrize.org. Nobel Media AB; 2021 [cited 2021 Oct 13]. Available from: https://www.nobelprize.org/ prizes/medicine/2014/may-britt-moser/biographical

24. The Nobel Prizes. Tu Youyou - Biographical [Internet]. NobelPrize.org. Nobel Media AB; 2021 [cited 2021 Oct 13]. Available from: https://www.nobelprize.org/prizes/ medicine/2015/tu/biographical

25. Huang J, Gates AJ, Sinatra R, Barabási AL. Historical comparison of gender inequality in scientific careers across countries and disciplines. Proc Natl Acad Sci U S A. 2020 Mar 3:117(9):4609-16. https://doi.org/10.1073/ pnas.1914221117

26. Mueller C, Wright R, Girod S. The publication gender gap in US academic surgery. BMC Surg. 2017:17(1):16-20. https://doi.org/10.1186/s12893-017-0211-4

27. Warner AS, Lehmann LS. Gender Wage Disparities in Medicine: Time to Close the Gap. J Gen Intern Med. 2019:34(7):1334-6. https://doi.org/10.1007/s11606019-04940-9
28. Modgil S, Gill R, Lakshmi Sharma V, Velassery S, Anand A. Nobel Nominations in Science: Constraints of the Fairer Sex. Ann Neurosci. 2018;25(2):63-78. https:// doi.org/10.1159/000481906

\section{Anna Maria Garcia Cardoso}

General Surgery Resident at São Lucas Hospital of Pontifical University Catholic of Rio Grande do Sul (PUCRS), Porto Alegre, RS, Brazil.

\section{Fernanda Santos Wengrover}

Medical Student at Federal University of Health Sciences of Porto Alegre (UFCSPA), Porto Alegre, RS, Brazil.

\section{Marcelo Garcia Toneto}

Adjunct Professor at School of Medicine of Pontifical University Catholic of Rio Grande do Sul (PUCRS), RS, Brazil; MSc at Clinical Medicine and PhD at Ciruigic Clinic from Pontifical University Catholic of Rio Grande do Sul (PUCRS), RS, Brazil; Head of the General Surgery and Gastrointestinal Surgery Services at São Lucas Hospital, Porto Alegre, RS, Brazil; Full Member of the Brazilian College of Surgeons.

\section{Mailing address}

Anna Maria Garcia Cardoso

Rua São Josemaria Escriva, 669, Unit 1008

Jardim do Salso, 91410-470

Porto Alegre, RS, Brazil

Os textos deste artigo foram revisados pela Poá Comunicação e submetidos para validação do(s) autor(es) antes da publicação. 